\title{
Relationship between Surface Water Temperature and Steelhead Distributions in Lake Michigan
}

\author{
TOMAS O. HöÖK,* EDWARD S. RutherFord, AND SHANNON J. BRINES \\ University of Michigan School of Natural Resources and Environment, \\ Ann Arbor, Michigan 48109-1084, USA
}

\author{
David J. Schwab and Michael J. McCormick \\ National Oceanic and Atmospheric Administration, \\ Great Lakes Environmental Research Laboratory, \\ Ann Arbor, Michigan 48105-1593, USA
}

\begin{abstract}
Salmonines support valuable recreational fisheries and are the predominant predators in the open waters of the Great Lakes, yet the spatial distributions of salmonines in these systems have not been fully documented. We analyzed the horizontal distributions of steelhead Oncorhynchus mykiss in Lake Michigan from 1992 to 1997 and related these distributions to mean surface temperature and temperature variation. We used angler catch rate data from Lake Michigan natural resources agencies to index the spatial and temporal distributions of steelhead and obtained surface water temperature data from advanced very-high-resolution radiometer satellite imagery through the National Oceanic and Atmospheric Administration's CoastWatch Program. During most months, steelhead catch rates were negatively related to surface temperature and were highest in areas of high temperature variation (i.e., vertical thermal fronts and upwelling zones) where thermal conditions and prey densities may have been optimal for growth. Our results demonstrate how remotely sensed and creel survey data can be integrated to allow for more effective exploitation and management of lakewide fish stocks while enabling researchers to generate and test hypotheses regarding the spatial distributions of fish populations.
\end{abstract}

The distributions of fish are often related to temperature. Fish may move to areas of preferred mean temperature to maximize growth, survival, and fitness (Magnuson et al. 1979; Crowder and Magnuson 1983; Dill 1987; Brandt 1993). Similarly, fish may be attracted to areas of sharp temperature variation, such as upwelling zones (Laurs et al. 1984; Fiedler and Bernard 1987), horizontal thermal fronts (Brandt 1980), and vertical thermal fronts (Aultman and Haynes 1993), that concentrate fish by aggregating prey (Norlin 1967; Brandt 1980; Le Fèvre 1986), that contain thermal conditions favorable for growth (Brandt 1993), or that create barriers to fish movement (Brandt and Wadley 1981).

The spatial and temporal distributions of Great Lakes salmonines (Haynes and Keleher 1986; Nettles et al. 1987; Olson et al. 1988), and specifically steelhead Oncorhynchus mykiss (Hansen and Stauffer 1971; Spigarelli and Thommes 1979; Haynes et al. 1986) are known to be influenced by temperature. Spigarelli and Thommes (1979) demonstrated that adult steelhead move to preferred temperatures near power plant thermal discharges.

\footnotetext{
* Corresponding author: thook@umich.edu
}

Received October 4, 2002; accepted May 9, 2003
Based on past studies (Kwain and McCauley 1978; Spigarelli and Thommes 1979; Haynes et al. 1986), Rand et al. (1993) assumed that steelhead in Lake Michigan occupy the warmest available temperatures throughout the year up to but not exceeding $19^{\circ} \mathrm{C}$ during their first year and $15^{\circ} \mathrm{C}$ thereafter. These preferred temperatures are similar to those reported by Coutant (1977) for rainbow trout. Haynes et al. (1986) hypothesized that steelhead in Lake Ontario aggregate in areas of sharp temperature variation, with pronounced aggregations along the spring thermocline. During the spring of 1990, Aultman and Haynes (1993) tested this hypothesis in southern Lake Ontario and documented higher salmonine catch rates at vertical thermal fronts than in unstratified waters.

The field studies cited above (Spigarelli and Thommes 1979; Haynes et al. 1986; Aultman and Haynes 1993) demonstrate that steelhead in the Great Lakes will select locations based upon thermal conditions. However, the spatial and temporal scales of these studies were limited. For instance, Aultman and Haynes (1993) limited their study to southern Lake Ontario during the period from April to June 1990. Recent technical advancements make it feasible to study the influence of temperature on fish distributions throughout large sys- 
tems over extended periods of time. Satellite imagery allows for daily measurements of surface temperatures throughout the Laurentian Great Lakes, and angler catch rates provide coarse, relative measures of fish abundance in distinct regions of these lakes. Steelhead primarily inhabit surface waters in the Pacific Ocean (Ruggerone et al. 1990; Burgner et al. 1992) and the Great Lakes (Aultman and Haynes 1993). Thus, it is both possible and appropriate to relate lakewide spatial distributions of steelhead to surface temperature.

Lake Michigan surface temperature data are available to the public through the National Oceanic and Atmospheric Administration's (NOAA) CoastWatch Program. It is therefore feasible for anglers to select their fishing locations based upon anticipated surface thermal conditions. Although anecdotal evidence suggests that anglers do target areas with particular thermal characteristics, we are unaware of any studies on the Great Lakes that have demonstrated an association between angler effort and surface temperature on a lakewide basis.

Our objectives were to determine whether lakewide steelhead distributions and angler effort in Lake Michigan were related to surface water temperature and how these potential relationships varied over time. To this end, we documented the distributions of steelhead in Lake Michigan from 1992 to 1997 by analyzing charter boat catch rate data and related the variation in catch rates and angler effort to surface temperatures quantified through satellite imagery. We hypothesized that both mean temperature and temperature variation would influence the temporal and spatial distributions of steelhead and anglers and that steelhead catch rates would be highest in areas with highly variable surface temperatures, mean temperatures near $15^{\circ} \mathrm{C}$, or both.

\section{Methods}

Steelhead catch rates.-We calculated charter boat angler catch rates based on creel data collected by the Illinois, Michigan, and Wisconsin Departments of Natural Resources from 1992 to 1997. These agencies divided the surface of Lake Michigan into a grid of $10^{\prime} \times 10^{\prime}$ cells $(273$ cells total; individual cells $\sim 13 \times 18 \mathrm{~km}$ ). For each fishing trip, charter boat captains recorded various data, including the date, location (i.e., $10^{\prime}$ grid cell fished in), number of anglers, hours spent fishing, and number and species of fish caught. Because different fishing trips targeted different species (i.e., some fishing trips targeted nonsalmonines such as yellow perch Perca flavescens), we only considered trips that evidently targeted salmonines (i.e., fishing trips during which at least one salmonine was captured). We calculated catch per unit effort (CPUE) for each trip as the number of steelhead caught divided by the number of anglerhours (time spent fishing multiplied by the number of anglers).

Surface temperatures.-We indexed surface temperatures through satellite advanced veryhigh-resolution radiometry imagery from NOAA's CoastWatch Program (Schwab et al. 1999). This program records surface temperatures for the Great Lakes at approximately a $2.6-\mathrm{km}$ resolution up to four times a day. We used data from this program to calculate two metrics of temperature for individual $10^{\prime}$ grid cells: (1) daily mean temperature and (2) daily temperature difference (the difference between the daily minimum and maximum temperatures recorded in a cell). The latter could be the result of short-term temporal or spatial variation in temperature within individual $10^{\prime}$ grid cells.

Temporal variation in catch rates and temperature.-We quantified steelhead catch rates, mean temperature, and mean temperature difference on a monthly lake-wide basis for May-September (i.e., those months with substantial angler effort). We calculated monthly lakewide catch rates by dividing the total number of steelhead caught by the total angler-hours for the entire lake. We calculated the lakewide mean monthly surface temperature, $T_{i j}$, for each month $j$ (May-September) and year $i(1992-1997)$ as

$$
T_{i j}=\sum_{k} \sum_{l} \frac{t_{i j k l}}{n_{i j}}
$$

in which $t_{i j k l}$ is the mean temperature in cell $l$ during day $k$ of the given month and year and $n_{i j}$ is the number of such observations during month $j$ in year $i$. Similarly, we calculated a monthly index of lakewide temperature variation, $D_{i j}$, as

$$
D_{i j}=\sum_{k} \sum_{l} \frac{d_{i j k l}}{n_{i j}},
$$

where $d_{i j k l}$ is the daily temperature difference within a specific cell in a given month and year.

To analyze the temporal variation in steelhead catch rates, we used SPSS (SPSS, Inc. 2001). Our intent was to use analysis of covariance (ANCO$\mathrm{VA}$ ) to compare the relative influences of temperature and seasonal effects on monthly lakewide catch rates. Based on plots of monthly lakewide steelhead CPUE versus $T_{i j}$ and $D_{i j}$, it was clear that 
the former did not vary linearly with either of the latter. Thus, based on visual inspection of these plots and the SPSS curve estimation procedure, we transformed $T_{i j}$ and $D_{i j}$ so that the relationship between monthly lakewide steelhead CPUE and these variables appeared to be linear. Then we performed two ANCOVAs to explain the variation in monthly lakewide steelhead CPUE; the first treated month and year as fixed factors and the transformed $T_{i j}$ as the covariate (based on the curvefitting exercise, we used $T_{i j}$ and the square of $T_{i j}$ as covariates, while the second treated month and year as fixed factors and the transformed $D_{i j}$ as the covariate (based on the curve-fitting exercise, we used the natural logarithm of $D_{i j}$ as the covariate).

Spatial variation in catch rates and temperature.-We analyzed the spatial variation in steelhead catch rates using maps and weighted mean estimates. We mapped steelhead CPUE for discrete time periods using ArcView GIS 3.2 (ESRI 2000). These maps suggested that steelhead CPUE was spatially positively autocorrelated. To test for autocorrelation, we used SpaceStat (Anselin 1999) to calculate Moran's $I$ and Gerry's $C$ coefficients, which indicated that steelhead cpue was indeed consistently positively autocorrelated $(\alpha=0.05)$. Spatial autocorrelation suggests that contiguous measurements are not independent, and lack of independence violates an assumption shared by several standard statistical tests (see Legendre 1993). With this in mind, we related the spatial variation in steelhead CPUE to temperature using lakewide weighted means and paired $t$-tests that did not treat contiguous measurements as independent observations.

We calculated a series of monthly lakewide weighted means to evaluate how surface temperature influenced where anglers fished and steelhead were caught. We calculated two lakewide weighted means of surface temperature and temperature difference for each month $j$ (MaySeptember) and year $i$ (1992-1997) as follows:

mean monthly temperature weighted by effort,

$$
\mathrm{TE}_{i j}=\frac{\sum_{k} \sum_{l} e_{i j k l} t_{i j k l}}{\sum_{k} \sum_{l} e_{i j k l}} ;
$$

mean monthly temperature difference weighted by effort,

$$
\mathrm{DE}_{i j}=\frac{\sum_{k} \sum_{l} e_{i j k l} d_{i j k l}}{\sum_{k} \sum_{l}} ;
$$

mean monthly temperature weighted by catch

$$
\mathrm{TC}_{i j}=\frac{\sum_{k} \sum_{l} c_{i j k l} t_{i j k l}}{\sum_{k} \sum_{l} c_{i j k l}} ; \quad \text { and }
$$

mean monthly temperature difference weighted by catch

$$
\mathrm{DC}_{i j}=\frac{\sum_{k} \sum_{l} c_{i j k l} d_{i j k l}}{\sum_{k} \sum_{l} c_{i j k l}} ;
$$

$e_{i j k l}$ is the amount of angler effort (hours spent fishing) in cell $l$ during day $k$ and $c_{i j k l}$ is the corresponding number of steelhead caught.

We grouped our weighted metrics of mean temperature and temperature variation by month (May-September) and used paired $t$-tests to compare them $(\alpha=0.05)$. For instance, to compare mean surface temperature weighted by effort $\left(\mathrm{TE}_{i j}\right)$ and by catch $\left(\mathrm{TC}_{i j}\right)$ for May, we established six pairs of data $\left(\mathrm{TE}_{i, \text { May }}\right.$ and $\mathrm{TC}_{i, \text { May }}$; one pair for each year) and compared these data with a paired $t$-test $(\mathrm{df}=5)$. For each month, our null hypotheses were that $T_{i j}=\mathrm{TE}_{i j}=\mathrm{TC}_{i j}$ and $D_{\mathrm{ij}}=\mathrm{DE}_{\mathrm{ij}}=\mathrm{DC}_{i j}$. Significant differences between $T_{i j}$ and $\mathrm{TE}_{i j}$ and between $D_{i j}$ and $\mathrm{DE}_{i j}$ would suggest an association between surface temperature and angler behavior. For instance, if $T_{i J u n e}$ were found to be greater than $\mathrm{TE}_{i J u n e}$, during the month of June (1992-1997) there was a tendency for anglers to fish in waters cooler than the lakewide mean. Similarly, significant differences between $\mathrm{TE}_{i j}$ and $\mathrm{TC}_{i j}$ and between $\mathrm{DE}_{i j}$ and $\mathrm{DC}_{i j}$ would suggest an association between surface temperature and steelhead CPUE. If $\mathrm{DE}_{i J u l y}$ were found to be less than $\mathrm{DC}_{i J u l y}$, during the month of July (1992-1997) there was a tendency for steelhead to be caught in areas with a higher daily temperature difference.

\section{Results}

\section{Temporal Variation in Catch Rates}

Mean lake-wide steelhead catch rates varied consistently among months but not among years. In general, catch rates were greatest in June and lowest in August. Steelhead catch rates closely tracked the variation in the index of mean monthly lakewide temperature difference, $D_{i j}$, and less closely the mean monthly lakewide surface temperature, $T_{i j}$ (Figure 1). The relationship between mean monthly temperature and steelhead CPUE most closely matched a quadratic model $\left(R^{2}=\right.$ $0.27, F=4.91$, df $=27, P<0.05$ ), with a maximum at $12.3^{\circ} \mathrm{C}$ (Figure 2). The relationship be- 

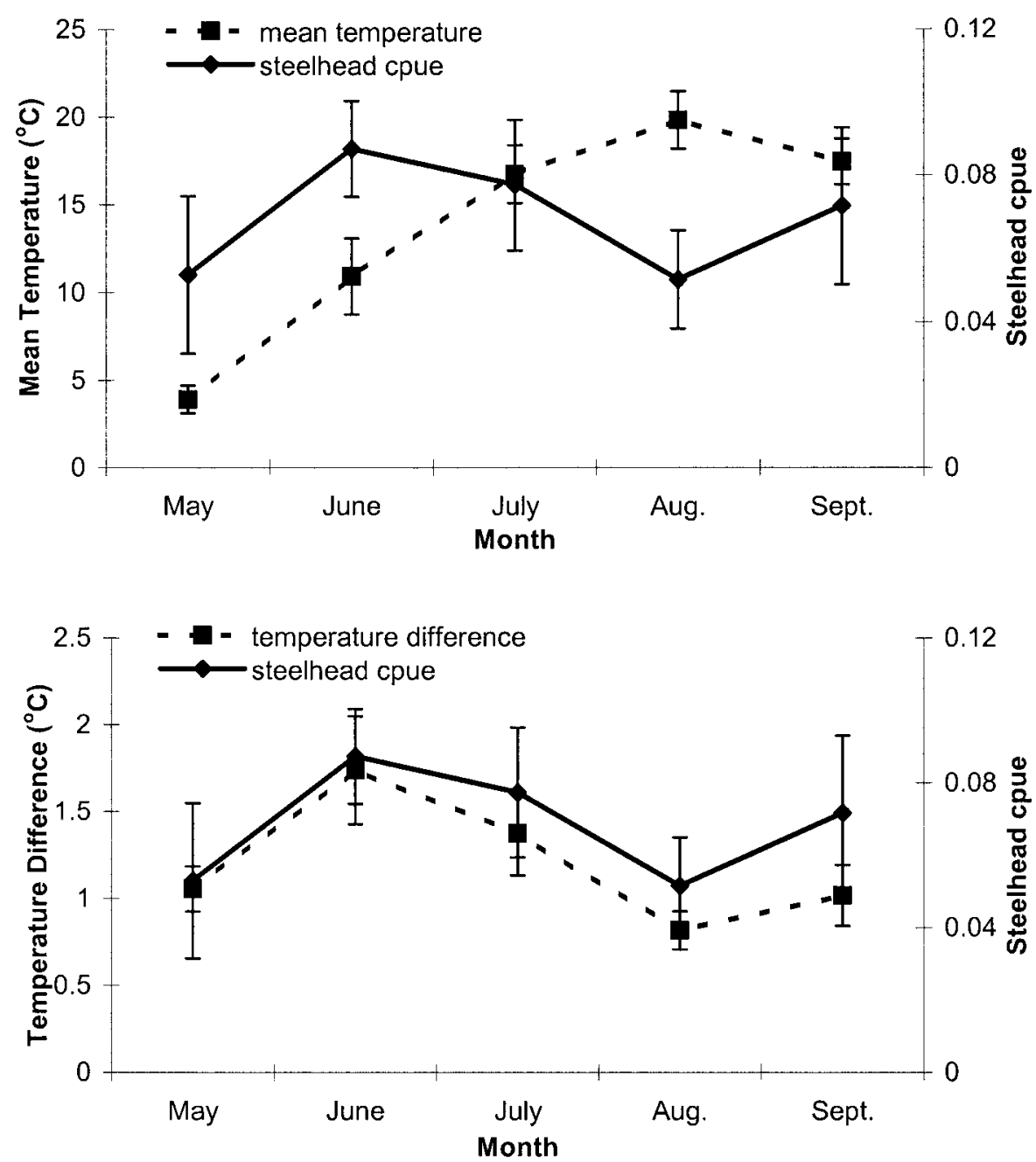

FIGURE 1.-Mean monthly lakewide steelhead catch per unit effort (CPUE) plotted with mean monthly surface temperature (upper panel) and mean monthly temperature difference (lower panel) in Lake Michigan, $1992-1997$. Each point represents the mean of six years (1992-1997); error bars represent 1 SD.

tween temperature difference and steelhead CPUE most closely matched a logistic model $\left(R^{2}=0.37\right.$, $F=16.41$, df $=28, P<0.05$; Figure 2).

The fact that both $T_{i j}$ and $D_{i j}$ varied consistently by month made it difficult to separate the relative influences of temperature and other seasonal effects on monthly lakewide steelhead catch rates. Although both ANCOVAs were significant (mean temperature as covariate: $R^{2}=0.68 ; F=3.50$; $\mathrm{df}=11,18 ; P=0.01$; temperature difference as covariate: $R^{2}=0.63 ; F=3.19$, df $=10,19 ; P=$ 0.01 ), the individual components (year, month, and temperature) of these two models were not significant.

\section{Spatial Variation in Catch Rates}

The spatial distributions of steelhead CPUE were not random according to Moran's $I$ and Gerry's $C$. Although angler effort was concentrated in the southern $75 \%$ of Lake Michigan and along the periphery of the lake, spatial trends were evident. During most months, steelhead CPUE tended to increase with latitude and, to a lesser degree, longitude (Figure 3).

Within months, there were consistent spatial relationships between angler effort and temperature (Figure 4). During May, June, and September, $\mathrm{TE}_{i j}$ (mean temperature weighted by effort) was significantly greater than $T_{i j}$ (lakewide mean temper- 


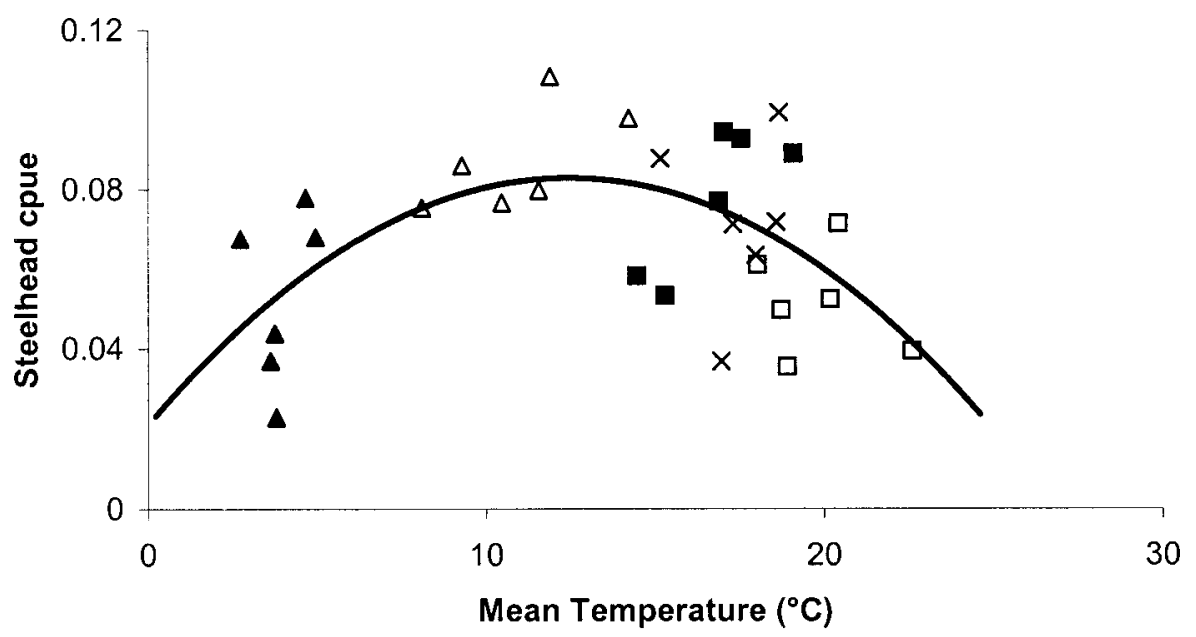

$\triangle$ May $\quad \Delta$ June July $\quad \square$ August $\times$ September

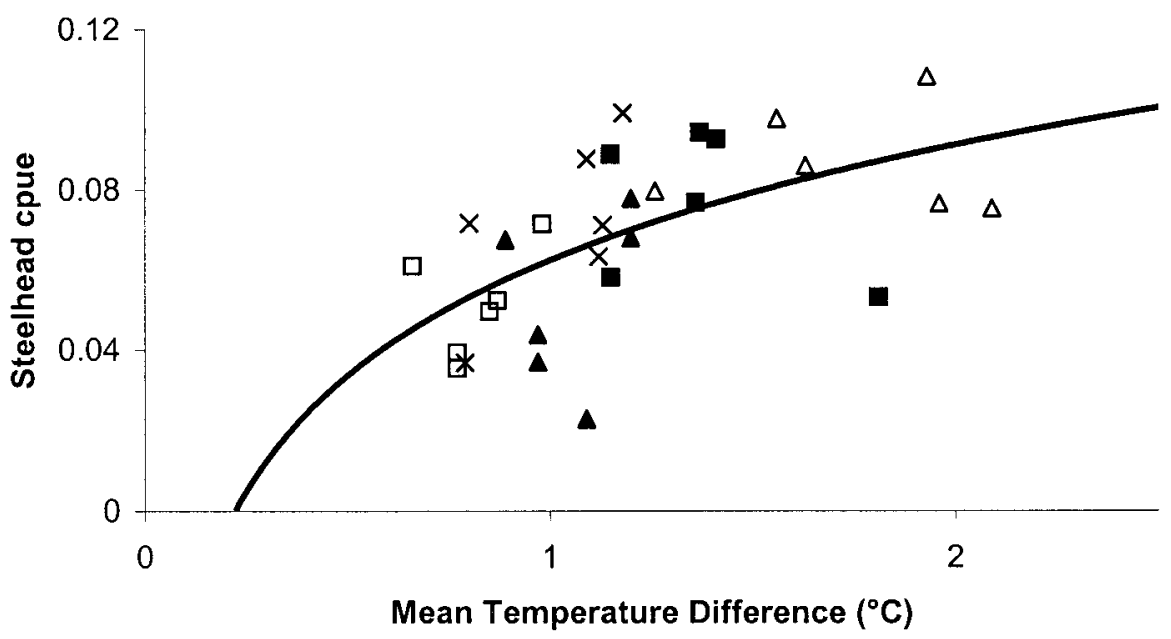

FIGURE 2.- Mean monthly lakewide steelhead CPUE plotted against mean monthly surface temperature (upper panel) and mean monthly temperature difference (lower panel) in Lake Michigan, 1992-1997. The fitted regression lines, in which the dependent variables are weighted by monthly fishing effort, are as follows: $y=0.0242+$ $0.0094 x-0.0004 x^{2}\left(R^{2}=0.27, F=4.91, P<0.05\right)$ for the upper panel and $y=0.0625+0.0405 \log _{e} x\left(R^{2}=\right.$ $0.37, F=16.41, P<0.05)$ for the lower panel.

ature), indicating that during these months anglers tended to select cells that were warmer than the lakewide average. Similarly, during May and August anglers tended to select cells with particularly high daily temperature differences (i.e., $\mathrm{DE}_{i j}$ was significantly greater than $D_{i j}$ ).

In general, steelhead catch rates were higher in cooler cells during warm months and higher in warmer cells during cool months (Figures 4, 5). During May (the coldest of our five study months), $\mathrm{TC}_{i j}$ was significantly greater than $\mathrm{TE}_{i j}$, indicating that of those cells sampled by anglers there was a tendency for catch rates to be higher in warmer cells. During all other months, $\mathrm{TC}_{i j}$ was less than 

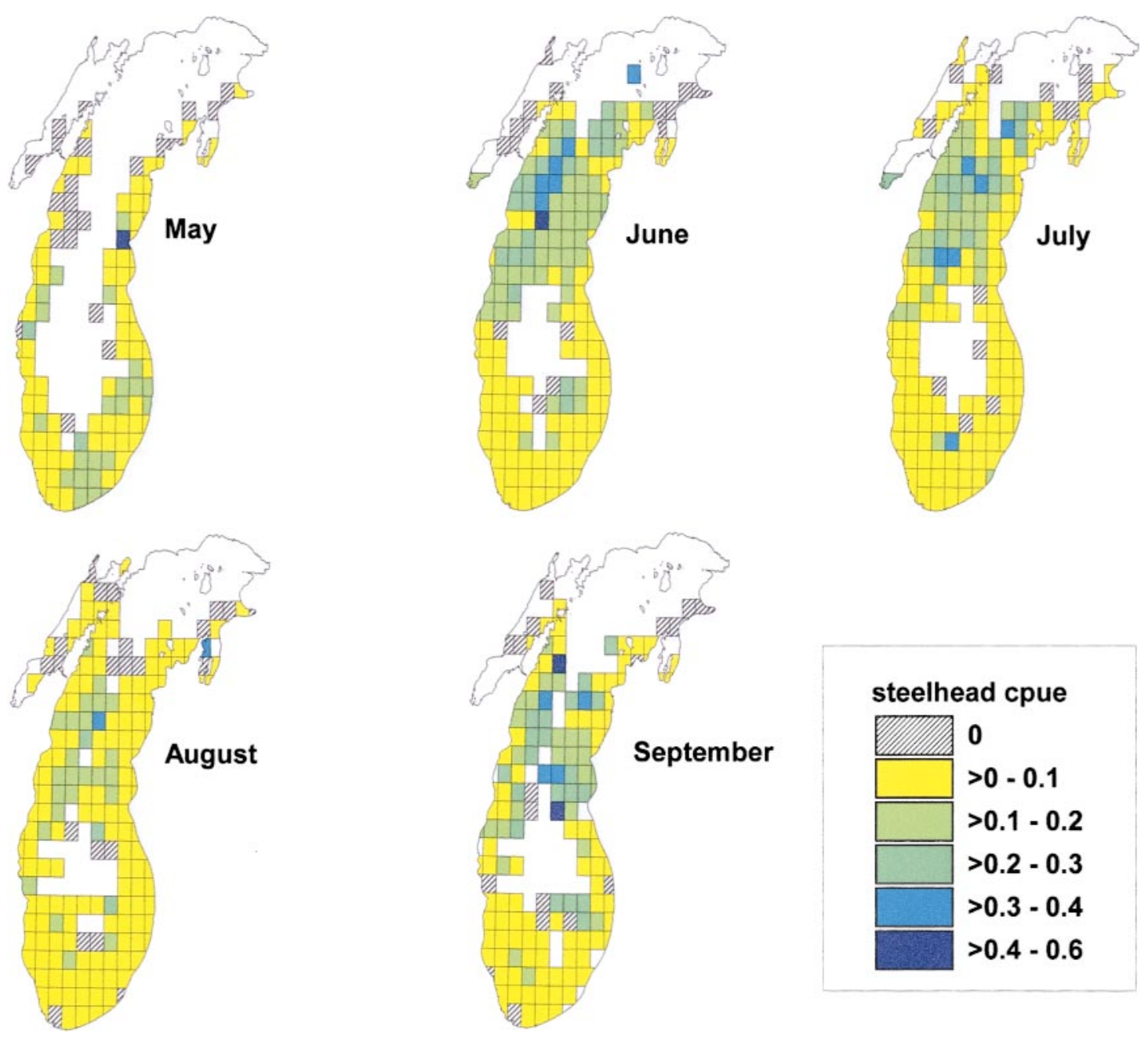

FigURE 3.- Mean steelhead CPUE within individual 10' grid cells aggregated by months between 1992 and 1997. White areas indicate no data.

$\mathrm{TE}_{i j}$ (significantly so during June, July, and September), indicating higher catch rates in cooler cells.

Local temperature variation also appeared to influence steelhead catch. Specifically, steelhead CPUE was consistently higher in cells with high temperature differences (Figures 4, 5). During all months, temperature difference weighted by catch $\left(\mathrm{DC}_{i j}\right)$ was greater than temperature difference weighted by effort $\left(\mathrm{DE}_{i j}\right)$, and significantly so during May, July, and August.

\section{Discussion}

Our study indicates that temperature consistently accounts for the variation in steelhead catch rates in Lake Michigan. In addition, our use of satellite imagery and creel data to examine the relationships between environmental factors and the spatial distributions of steelhead and anglers demonstrates how such techniques can be applied to study natural resources in the Great Lakes. Other studies (Laurs et al. 1984; Fiedler and Bernard 1987) have used similar methods to compare environmental factors and marine fish populations. The further development of these technologies should allow for continued, lakewide ecological studies of the Great Lakes.

Steelhead appeared to concentrate in different regions throughout the year, perhaps as a response to changing mean temperatures (steelhead CPUE was high in the south early in the year and in the north late in the year; Figure 3). Although Rand 

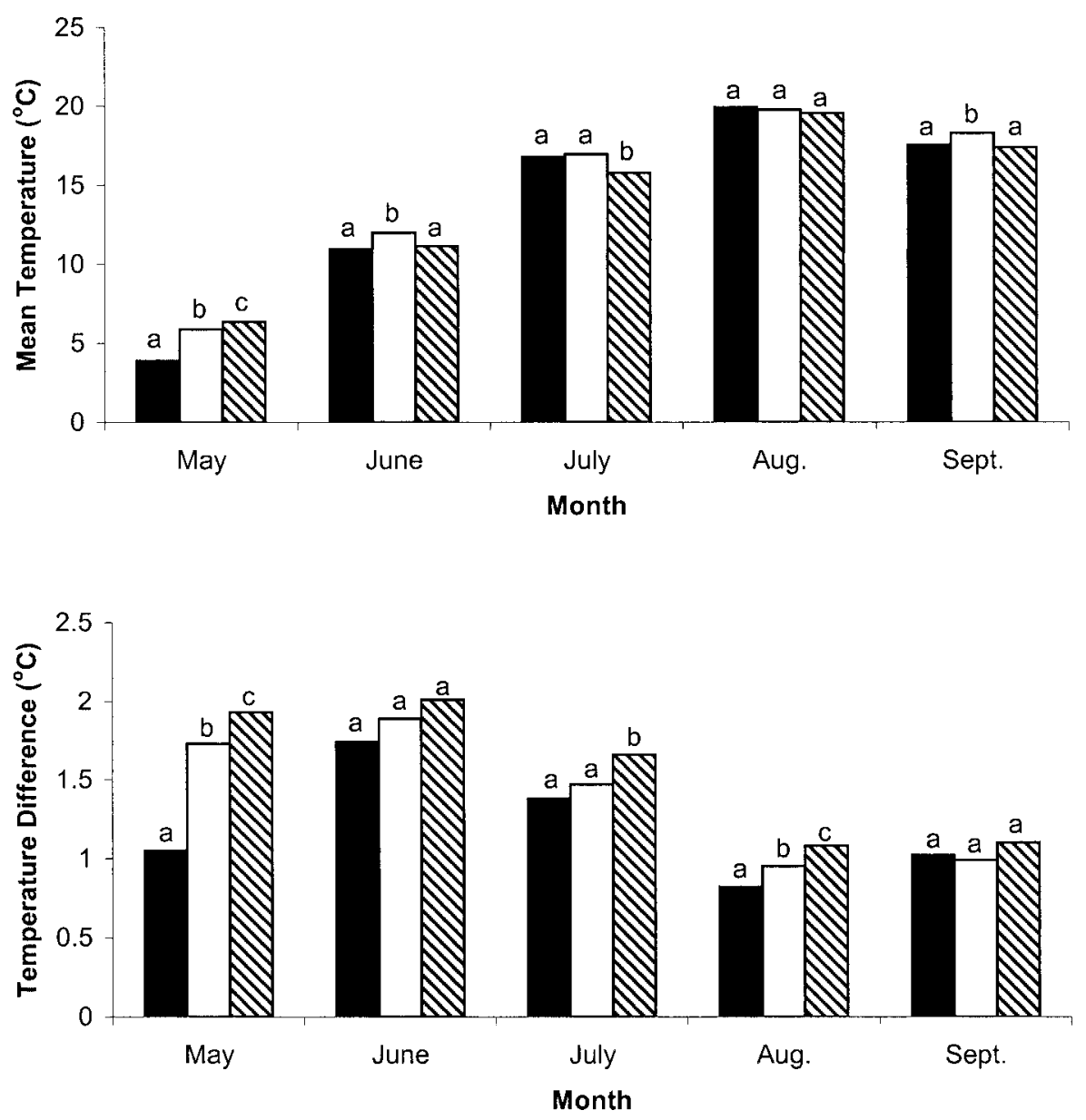

FIGURE 4.-Comparison of mean temperature (upper panel) and temperature difference values (lower panel) in Lake Michigan according to whether they are unweighted (dark bars), weighted by angler effort (white bars), or weighted by steelhead catch (crosshatched bars). Each bar represents the temperature statistic for that month averaged over 6 years (1992-1997). Within months, means with different letters are significantly different.

et al. (1993) assumed that adult steelhead in Lake Michigan occupy the warmest available temperatures not exceeding $15^{\circ} \mathrm{C}$, our findings show that steelhead CPUE in Lake Michigan was greatest at surface temperatures less than $15^{\circ} \mathrm{C}$ (Figure 5). For instance, during June 1992-1997 the mean temperature at which fishing occurred was $12^{\circ} \mathrm{C}$ while the mean temperature at which steelhead were caught was $11^{\circ} \mathrm{C}$, suggesting a preference for cooler temperatures (Figure 4). These findings are consistent with past comparisons of steelhead distributions and temperatures in the Pacific Ocean, which indicated that the highest steelhead densities occurred at temperatures below their supposedly preferred temperature of $15^{\circ} \mathrm{C}$ (Sutherland 1973; Okazaki 1983; Burgner et al. 1992). Although the temperatures preferred by nonanadromous rain- bow trout decrease with age (Kwain and McCauley 1978; Spigarelli and Thommes 1979), McCauley et al. (1977) and Garside and Tait (1958) have reported temperature preferenda of $11.3^{\circ} \mathrm{C}$ and $13^{\circ} \mathrm{C}$, respectively, for yearling rainbow trout. Thus, temperature preferenda suggested by many other authors (see Coutant 1977) may not match the temperatures actually occupied by adult steelhead in Lake Michigan. Nonetheless, it should be noted that this conclusion is based on the assumptions that steelhead CPUE is a coarse indicator of steelhead density and that steelhead occupy the top portion of the water column. Steelhead CPUE may reflect not only density but also angler skill and feeding activity level (Aultman and Haynes 1993). However, failure to account for the latter would probably lead to overestimates of 

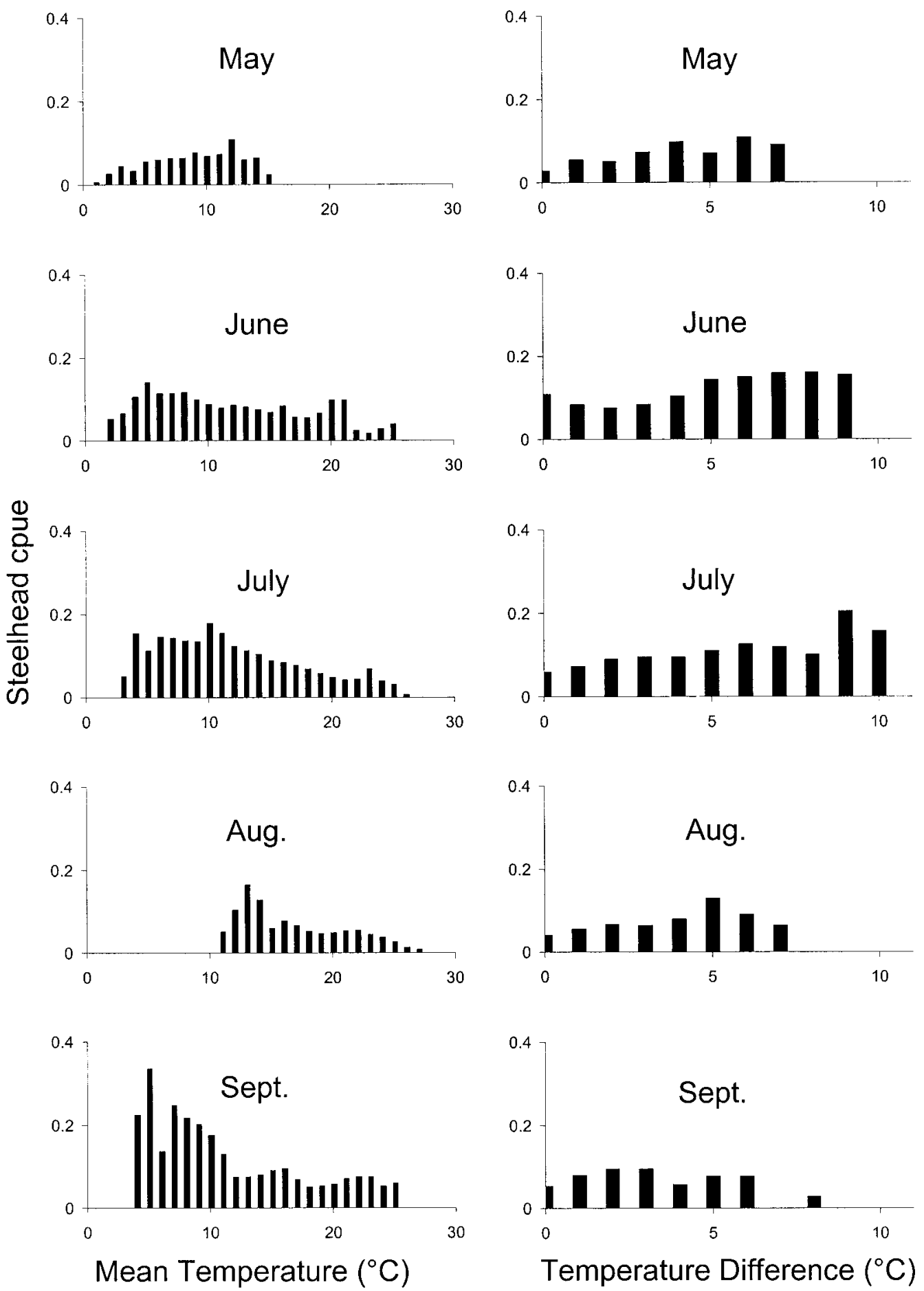

FIGURE 5.-Mean steelhead CPUE in Lake Michigan plotted against mean daily temperature (left-hand panels) and mean daily temperature difference (right-hand panels) in May-September 1992-1997. 
the average ambient temperatures experienced by steelhead. That is, feeding activity (and thus CPUE) would probably increase with temperature. If individual steelhead undertake excursions into deeper water, then surface water temperatures would not be indicative of the thermal conditions experienced by these individuals. Instead, these steelhead would experience even cooler thermal conditions (during summer, surface waters are generally warmer than deeper waters) and would cause us to overestimate the average ambient temperatures experienced by steelhead. Even so, further study will probably be necessary before rejecting $15^{\circ} \mathrm{C}$ as the thermal preferendum of steelhead in Lake Michigan.

Our finding that steelhead CPUE was highest in relatively cold areas suggests that steelhead respond to factors other than mean temperature. Crowder and Magnuson (1983) suggested that to maximize growth fish would occupy relatively cold temperatures when food resources are limited. Laboratory studies have demonstrated that rainbow trout will actively select lower temperatures when starved (Javaid and Anderson 1967), and several other fish species, including cisco Coregonus artedi (Rudstam and Magnuson 1985) and Atlantic cod Gadus morhua (Despatie et al. 2001) appear to select relatively cold temperatures when food densities are low. In addition, we found that steelhead CPUE was often highest in the western portion of the lake, where Brandt et al. (1991) reported high densities of alewives Alosa pseudoharengus, a preferred prey of steelhead. Thus, the spatial distribution of steelhead in Lake Michigan is consistent with the hypothesis that these fish respond to spatial variation in forage.

We found that steelhead CPUE increased with the daily temperature difference, which is consistent with studies in Lake Ontario (Haynes et al. 1986; Aultman and Haynes 1993) and anecdotal accounts from anglers. Frontal areas may serve as ecotones between different thermal habitats, increasing local diversity and facilitating a variety of trophic interactions (Le Fèvre 1986). Thermal fronts in the Great Lakes are important in structuring nutrient and lower-trophic-level distributions (Moll et al. 1993), and marine fish aggregate in such areas (Blackburn 1969; Laurs et al. 1984; Fiedler and Bernard 1987). Although the aggregation of steelhead in frontal areas is not surprising, the mechanisms leading to this behavior are unclear. Steelhead may be responding to a combination of favorable temperatures and prey densities. Based on thermoregulation strategies, fish may aggregate in areas of high temperature variation to maximize their biological growth potential (Brandt 1993). Physical processes may lead terrestrial insects to accumulate at vertical thermal fronts in the Great Lakes (Norlin 1967; Stewart and Ibarra 1991; Rand et al. 1993), thereby providing easily captured prey for steelhead, which are known to feed on such food items in the spring (Brandt 1986; Rand et al. 1993).

Our study demonstrates how remotely sensed and creel data can be integrated to allow anglers and managers to more effectively exploit and manage fish stocks while helping researchers to develop and test hypotheses across large systems. By targeting specific areas, anglers may increase their catches. Our results demonstrate that anglers do not select their locations randomly but instead appear to concentrate in areas with particular thermal conditions. Aultman and Haynes (1993) suggest that this type of angler behavior could lead to the overexploitation of certain fish stocks. This is probably not a major concern for managers around Lake Michigan, as the steelhead fishery and other salmonine fisheries in Lake Michigan rely heavily upon stocking. A primary management goal for stocked fisheries is often to maximize catches for one's constituents. The type of analysis we present could, however, influence stocking practices by revealing where fish tend to be caught. That is, in the case of a multijurisdictional fishery such as that for Lake Michigan steelhead, individual fish that are stocked in one jurisdiction may well be caught in another jurisdiction. The relative likelihood of such occurrences should influence stocking practices. For example, if the majority of Lake Michigan steelhead are caught in Wisconsin waters, it is probably not in Indiana's interest to stock the majority of steelhead into the lake.

The integration of remotely sensed and creel data also allows for developing and testing hypotheses across large systems. Haynes et al. (1986) and Aultman and Haynes (1993) hypothesized that Great Lakes steelhead aggregate along spring thermal fronts. Even though we used somewhat different methodologies to examine a different system at different temporal and spatial scales, we reached similar conclusions. This type of analysis can also be hypothesis generating. Our study suggests that steelhead in Lake Michigan tend to occupy cooler waters than previously assumed. This possibility should be further examined (perhaps by tagging and tracking the thermal history of individual fish) because the assumed thermal history of important predators can impact management 
models, particularly bioenergetics-based models (e.g., Stewart and Ibarra 1991).

\section{Acknowledgments}

We thank Dan Makauskas (Illinois DNR), Jerry Rakoczy (Michigan DNR), and Brad Eggold (Wisconsin DNR) for providing creel data. Further, we thank Sandy Arlinghaus, Doran Mason, James Haynes, Dana Aultman, and an anonymous reviewer for providing helpful comments on a previous version of this manuscript. Funding for this project was provided by a grant from the Michigan Department of Natural Resources and a fellowship from the University of Michigan's Cooperative Institute for Limnology and Ecosystems Research under cooperative agreement NA67RJ0148 from the Office of Oceanic and Atmospheric Research, National Oceanic and Atmospheric Administration (NOAA), U.S. Department of Commerce. This is contribution 1295 of NOAA's Great Lakes Environmental Research Laboratory.

\section{References}

Anselin, L. 1999. SpaceStat, version 1.9. BioMedware, Inc., Ann Arbor, Michigan. Available: www. spacestat.com.

Aultman, D. C., and J. M. Haynes. 1993. Spring thermal fronts and salmonine sport catches in Lake Ontario. North American Journal of Fisheries Management 13:502-510.

Blackburn, M. 1969. Conditions related to upwelling which determine distribution of tropical tunas off western Baja California. Fishery Bulletin 68:147176.

Brandt, S. B. 1980. Spatial segregation of adult and young-of-the-year alewives across a thermocline in Lake Michigan. Transactions of the American Fisheries Society 109:469-478.

Brandt, S. B. 1986. Food of trout and salmon in Lake Ontario. Journal of Great Lakes Research 12:200205.

Brandt, S. B. 1993. The effect of thermal fronts on fish growth: a bioenergetics evaluation of food and temperature. Estuaries 16:142-159.

Brandt, S. B., D. M. Mason, E. V. Patrick, R. L. Argyle, L. Wells, and D. J. Stewart. 1991. Acoustic measures of the abundance and size of pelagic planktivores in Lake Michigan. Canadian Journal of Fisheries and Aquatic Sciences 48:894-908.

Brandt, S. B., and V. A. Wadley. 1981. Thermal fronts as ecotones and zoogeographic barriers in marine and freshwater systems. Proceedings of the Ecological Society of Australia 11:13-26.

Burgner, R. L., J. T. Light, L. Margolis, T. Okazaki, A. Tautz, and S. Ito. 1992. Distribution and origins of steelhead trout Oncorhynchus mykiss in offshore waters of the north Pacific Ocean. International North Pacific Fisheries Commission Bulletin 51:1-92.
Coutant, C. 1977. Compilation of temperature preference data. Journal of the Fisheries Research Board of Canada 34:739-745.

Crowder, L. B., and J. J. Magnuson. 1983. Cost-benefit analysis of temperature and food resource use: a synthesis with examples from the fishes. Pages 189221 in W. P. Aspey and S. I. Lustick, editors. Behavioral energetics: vertebrate costs of survival. Ohio State University Biosciences Colloquia, No. 7. Ohio State University Press, Columbus.

Despatie, S.-P., M. Castonguay, D. Chabot, and C. Audet. 2001. Final thermal preferendum of Atlantic cod: effect of food ration. Transactions of the American Fisheries Society 130:263-275.

Dill, L. M. 1987. Animal decision making and its ecological consequences: the future of aquatic ecology and behaviour. Canadian Journal of Zoology 65: 803-811.

ESRI (Environmental Systems Research Institute). 2000. ArcView GIS, version 3.2. ESRI, Redlands, California.

Fiedler, P. C., and H. J. Bernard. 1987. Tuna aggregation and feeding near fronts observed in satellite imagery. Continental Shelf Research 7(8):871-881.

Garside, E. T., and J. S. Tait. 1958. Preferred temperature of rainbow trout (Salmo gairdneri) and its unusual relationship to acclimation temperature. Canadian Journal of Zoology 36:563-567.

Haynes, J. M., and C. J. Keleher. 1986. Movements of Pacific Salmon in Lake Ontario in spring and summer: evidence for wide dispersal. Journal of Freshwater Ecology 3:289-297.

Haynes, J. M., D. C. Nettles, K. M. Parnell, M. P. Voiland, R. A. Olson, and J. D. Winter. 1986. Movements of rainbow steelhead (Salmo gairdneri) trout in Lake Ontario and a hypothesis for the influence of spring thermal structure. Journal of Great Lakes Research 12(4):304-313.

Hansen, M. J., and T. M. Stauffer. 1971. Comparative recovery of the creel, movement, and growth of rainbow trout stocked in the Great Lakes. Transactions of the American Fisheries Society 100:336349.

Javaid, M. Y., and J. M. Anderson. 1967. Influence of starvation on selected temperature of some salmonids. Journal of the Fisheries Research Board of Canada 24:1515-1519.

Kwain, W., and R. W. McCauley. 1978. Effects of age and overhead illumination on temperatures preferred by underyearling rainbow trout, Salmo gaird$n e r i$, in a vertical temperature gradient. Journal of the Fisheries Research Board of Canada 35:14301433.

Laurs, R. M., P. C. Fiedler, and D. R. Montgomery. 1984. Albacore tuna catch distributions relative to environmental features observed from satellites. DeepSea Research 31:1085-1099.

Le Fèvre, J. 1986. Aspects of the biology of frontal systems. Advances in Marine Biology 23:163-299.

Legendre, P. 1993. Spatial autocorrelation: trouble or new autocorrelation? Ecology 74:1659-1673.

Magnuson, J. J., L. B. Crowder, and P. A. Medvick. 1979. 
Temperature as an ecological resource. American Zoologist 19:331-343.

McCauley, R. W., J. R. Elliot, and L. A. A. Read. 1977. Influence of acclimation temperature on preferred temperature in the rainbow trout Salmo gairdneri. Transactions of the American Fisheries Society 106: 362-365.

Moll, R. A., A. Braktovich, W. Y. B. Chang, and P. Pu. 1993. Physical, chemical, and biological conditions associated with the early stages of the Lake Michigan vernal thermal front. Estuaries 16:92-103.

Nettles, D. C., J. M. Haynes, R. A. Olson, and J. D. Winter. 1987. Seasonal movements of brown trout (Salmo trutta) in south-central Lake Ontario. Journal of Great Lakes Research 13(2):168-177.

Norlin, A. 1967. Terrestrial insects in lake surfaces: their availability and importance as fish food. Drottningholm Institute of Freshwater Research Report No. 47:39-55.

Okazaki, T. 1983. Distribution and seasonal abundance of Salmo gairdneri and Salmo mykiss in the North Pacific Ocean. Japanese Journal of Ichthyology 30: 235-246.

Olson, R. A., J. D. Winter, D. C. Nettles, and J. M. Haynes. 1988. Resource partitioning in summer by salmonids in south-central Lake Ontario. Transactions of the American Fisheries Society 117:552559.

Rand, P. S., D. J. Stewart, P. W. Seelbach, M. L. Jones, and L. R. Wedge. 1993. Modeling steelhead population energetics in Lakes Michigan and Ontario.
Transactions of the American Fisheries Society 122: 977-1001.

Rudstam, L. G., and J. J. Magnuson. 1985. Predicting the vertical distribution of fish populations: analysis of cisco, Coregonus artedii, and yellow perch, Perca flavescens. Canadian Journal of Fisheries and Aquatic Sciences 42:1178-1188.

Ruggerone, G. T., T. P. Quinn, I. A. McGregor, and T. D. Wilkinson. 1990. Horizontal and vertical movements of adult steelhead trout, Oncorhynchus mykiss, in the Dean and Fisher channels, British Columbia. Canadian Journal of Fisheries and Aquatic Sciences 47:1963-1969.

Schwab, D. J., G. A. Leshkevich, and G. C. Muhr. 1999. Automated mapping of surface water temperature in the Great Lakes. Journal of Great Lakes Research 25(3):468-481.

Spigarelli, S. A., and M. M. Thommes. 1979. Temperature selection and estimated thermal acclimation by rainbow trout (Salmo gairdneri) in a thermal plume. Journal of the Fisheries Research Board of Canada 36:366-376.

SPSS, Inc. 2001. SPSS, version 11.0. SPSS, Inc., Chicago, Illinois.

Stewart, D. J., and M. Ibarra, M. 1991. Predation and production by salmonine fishes in Lake Michigan. Canadian Journal of Fisheries and Aquatic Sciences 30:1327-1336.

Sutherland, D. F. 1973. Distribution, seasonal abundance, and some biological features of steelhead trout, Salmo gairdneri, in the North Pacific Ocean. Fisheries Bulletin 71:787-826. 